\title{
Kelebihan dan kekurangan penggunaan radiasi dosis rendah (Low Doses Radiation: advantages and disadvantages)
}

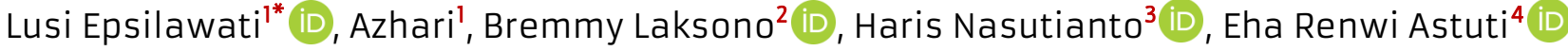

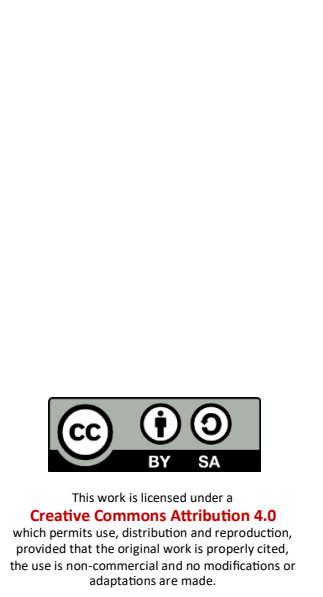

ABSTRACT

Objectives: To inform and discuss the benefits and beneficial effects on the body.

harms of low dose radiation.

Literature Review: Low dose radiation (LDR) was often used, including for services in the field of dentistry. Several studies have studied this for a long time but the results are still not conclusively agreed. Some researchers found a variety of side effects that are not beneficial to the body, but some found no association with the body damage caused by this, and even some found that LDR has
Conclusion: low doses of radiation cause significant changes in the body, although this condition is met with an adaptive reaction which is considered a beneficial response by the body. Therefore, no matter how small the radiation is given, it will still have an impact on the body so it is better to be wise in its use.

Keywords: Low dose radiation, excess use of low dose radiation, disadvantage of using low dose radiation Cite this article: Epsilawati L, Azhari, Laksono B, Nasutianto H, Astuti ER. Kelebihan dan kekurangan penggunaan radiasi dosis rendah. Jurnal Radiologi Dentomaksilofasial Indonesia 2020;4(3)117-23. https://doi.org/10.32793/jrdi.v4i3.633

\section{PENDAHULUAN}

Pengunaan dosis tinggi pada pelayanan di bidang radiologi dapat menyebabkan berbagai efek biologis yang cukup membahayakan bagi kesehatan, seperti menyebabkan mutasi, apoptosis, kanker, atau bahkan kematian. ${ }^{1,2}$ Kondisi berbeda apabila digunakan peralatan dengan dosis rendah radiasi. Beberapa penelitian melaporkan bahwa dosis rendah radiasi tidak membawa pengaruh berarti bagi kesehatan. Pernyataan ini menimbulkan banyak perdebatan, karena beberapa penelitian melaporkan tentang efek negatif yang berpengaruh pada tubuh. ${ }^{1,3}$ Namun, dalam dua dekade terakhir, beberapa penelitian melaporkan bahwa penggunaan radiasi dosis rendah justru memiliki efek yang menguntungkan pada organisme hidup, seperti meningkatkan kekebalan tubuh, anti-inflamasi, menstabilkan hormon, stimultan terhadap pertumbuhan sel, memberikan efek kematian pada sel kanker dan lainsebagainya..$^{3-8} \mathrm{Hal}$ ini juga mendapatkan bantahan dari sebagian peneliti yang mempercayai adanya keburukan dari penggunaan dosis rendah radiasi. ${ }^{8}$

International Commission on Radiological Protection (ICRP), merekomendasikan hipotesis linear no-threshold (LNT) sebagai ketetapan batas aman penggunaan dosis radiasi, dimana dikatakan bahwa pada dosis yang lebih rendah dari $200 \mathrm{mSv}$ ditentukan sebagai batas radiasi dosis rendah oleh
United Nations Scientific Committee on the Effects of Atomic Radiation (2016). Berbagai penyakit seperti contohnya perkembangan kanker, dikatakan sebagai salah satu resiko penggunaan dosis rendah radiasi yang bahkan lebih rendah dari nilai $200 \mathrm{mSv}^{9,10}$

Selanjutnya, pemeriksaan difokuskan pada reaksi adaptif sistemik pada hewan yang terpapar radiasi dosis rendah, dan ditemukan adanya perubahan molekuler dalam sel akibat terjadi reaksi adaptif secara sistemik. Radiasi berinteraksi dengan atom dan molekul dalam sel dan menyebabkan kerusakan pada DNA, dan hal ini yang tetap dipercaya sebagai sumber adanya risiko kanker. Perubahan basa DNA dan /atau gangguan pada hubungan cross DNA-protein, dapat diinduksi oleh radiasi. ${ }^{11.12}$ Perubahan molekuler ini menyebabkan ketidakstabilan genom, yang umumnya terdeteksi dengan pemeriksaan DSB, penyimpangan kromosom, frekuensi mikronuklei (MNs) dan regulasi responsif stres gen. Kondisi ini merupakan fenomena yang belum terpecahkan secara pasti. ${ }^{11}$

Artikel ini membahas fenomena penggunaan radiasi dosis rendah terhadap tubuh. Adapun tujuan dari penulisan artikel ini adalah untuk berbagi informasi dan mendiskusikan tentang bahaya dan manfaat radiasi dosis rendah, khususnya di bidang kedokteran gigi. 


\section{STUDI PUSTAKA}

\section{KEKURANGAN PENGGUNAAN RADIASI DOSIS RENDAH (LDR)}

Penggunaan radiasi pengion (sinar-x) berperan sangat penting di bidang kedokteran gigi sebagai alat bantu dalam menetapkan diagnosis, menentukan rencana perawatan dan evaluasi hasi perawatan. Sulit dibayangkan pada masa sekarang, apabila tidak terdapat pencitraan sinar- $X$ sepert diantaranya pengunaan $\mathrm{CT}$ dan plaint radiografi dan lainnya terutama pada perawatan gigi dan mulut. ${ }^{12}$ Radiasi pengion selain digunakan untuk diagnosis juga digunakan untuk terapi khususnya pada pengobatan kanker. Radiasi pengion dosis tingg dapat membunuh manusia atau organisme hidup lainnya karena sinar pengion juga bersifat karsinogenik. Oleh karena itu, radiasi pengion harus digunakan dengan hati-hati, baik yang berdosis tinggi maupun yang berdosis rendah. Radiasi dengan dosis kumulatif hingga $100 \mathrm{mSv}$ yang disebut sebagai radiasi dosis rendah, memilik efek terhadap tubuh yang tetap dapat dirasakan. ${ }^{12}$

Radiasi dosis rendah (LDR) yang mengenai tubuh akan berinteraksi dengan atom dan moleku pada sel, keadaan ini dipercaya dapat menyebabkan beberapa kerusakan seperti kerusakan DNA, yang meningkat risiko kanker kondisi ini terjadi apabila sinar-x mengganggu pada proses atau anatoni Single-strand breaks (SSBs) double-strand breaks (DSBs), DNA base alterations dan DNA-DNA atau DNA-protein cross-links, dimana keseluruhan perubahan ini menyebabkan ketidaksatabilan gemon yang memicu terjadinya mutasi. ${ }^{14}$

DNA DSB adalah lesi sitotoksik utama yang disebabkan oleh radiasi pengion, dimana berdasarkan beberapa penelitian ditemukan bahwa terdapat hubungan linier antara radiasi dan mutasi/ kematian sel. Respon kerusakan DNA yang disebabkan oleh radiasi tunggal pada dosis tinggi sudah memberikan efek yang nyata dan jelas, sedangkan efek pada penggunaan dosis rendah radiasi yang berjangka panjang belum ditentukan dan beberapa penelitian pun telah dilakukan. ${ }^{15}$ Tabel 1 dibawah ini, memperlihatkan beberapa penelitian yang telah dilakukan untuk menilai perubahan yag terjadi pada DNA sel akibat pemanfaatan dosis rendah $x$-Ray.

Berdasarkan beberapa penelitian terlihat bahwa 5 peneliti menyatakan mendukung bahwa LDR merusak tubuh, sedangkan 2 lainnya menyatakan tidak saling berkaitan.

Dosis rendah radiasi (LDR) selain merusak juga menyebabkan respons adaptif secara sistemik, hal ini dibuktikan dari beberapa penelitian yang dilakukan pada hewan coba yang diberikan radias dosis rendah. Penelitian tersebut memperlihatkan bahwa terjadi respon adaptif yang menuju ke arah merugikan bagi tubuh, contohnya dimana terjad peningkatkan kecepatan perbaikan DNA DSB pasca pemberian radiasi dosis rendah (10 dan $20 \mathrm{mGy}$ ) Penelitian serupa, juga membuktikan bahwa pemberian LDR dengah dosis $20 \mathrm{mGy}$ dan 0,1 Gy, mampu meregulasi efek sitotoksik antitumor dan menurunkan apoptosis sel terutama pada sel natural killer. ${ }^{30,31}$ Penelitian selanjutnya membuktikan bahwa LDR tidak memberikan pengaruh apapun. ${ }^{32}$

Reaksi adaptif juga terjadi pada sistem hematopoietik setelah menerima $3 \mathrm{mGy}$, dosis ini merupakan dosis yang sangat rendah. Cuttler et al, dalam penelitiannya membuktikan bahwa terjadi peningkatan masa hidup pada anjing beagle setelah dilakukan pemberian 50 mGy dalam durasi 30 hari dalam setahun, dan akan mengalami kematian begitu diberikan 1,9 mGy/hari/tahun. Ini membuktikan bahwa pemberikan radiasi dosis rendah yang berkali-kali akan membahayakan sedangkan, pada pemberian dosis radiasi yang diberi jeda waktu akan memberikan efek bermanfaat. $^{33}$ Seed et al, juga melaporkan bahwa terdapat respon adaptif terhadap LDR pada sistem pembentuk darah pada percobaan pencabutan gigi taring pada tikus, efek yang terlihat bahwa terdapat penurunan jumlah leukosit dan trombosit pada tikus pasca radiasi. ${ }^{34}$ Geofery Luntsi et al, juga meneliti hal yang serupa yaitu efek LDR terhadap respon adaptif pada sistem haemapoitik, dengan menggunakan hewan babi yang diberikan $x$-ray dosis $12,5 \mathrm{mGy}$, dimana dilakukan pengulangan waktu pemberian radiasi berdasarkan pengulangan waktu yaitu 1, 24, 72, 163 dan 336 jam, kemudian darah babi diperiksa. Hasil hitung leukosit menunjukkan terjadi penurunan jumlah leukosit setiap kali post penyinaran, dan terlihat bahwa setiap kali penyinaran maka jumlah lekosit akan menurun dengan perbandingan linier terhadap hari penyinaran. $^{34}$

Penelitian terbaru mengenai LDR, membuktikan bahwa terdapat hubungan antara LDR dan penyakit neurodegeneratif. Penyakit neurogenetif adalah penyakit pada sistem syaraf yang menyebabkan demensia. Hipotesis awal pada penelitian ini menduga bahwa pencitraan sinar- $X$ yang biasa digunakan dalam praktik gigi mungkin merupakan faktor penyebab penyakit neurodegeneratif. ${ }^{35}$ Risiko dari radiografi gigi yang dilakukan berulang kali, seringkali mengabaikan atau mengambil prinsip sebagai berikut: 1) dosis yang digunakan dalam radiografi gigi dianggap sebagai sesuatu yang tidak membahayakan, 2) satusatunya efek biologis yang dipercaya dari LDR hanya kanker, mutasi yang dapat diwariskan, dan pemendekan masa hidup, 3) jumlah LDR yang digunakan untuk pencitraan diagnostik dianggap sangat rendah sehingga tidak mungkin untuk membedakan suatu kasus yang diakibatkan radiasi akibat medikal atau alami, 4) jaringan mengalami resistemsi terhadap radiasi karena neuron pada orang dewasa tidak aktif membelah, dan cenderung dikatakan aman terhadap radiasi, sednagkan kerusakan DNA akibat radiasi masih dimungkinkan dan, 5) risiko yang diakibatkan radiasi gigi dirasa lebih penting apabila dibandingkan risiko teoretis. ${ }^{35}$ Berdasarkan penelaahan, radiasi dosis rendah memulai rangkaian efek yang sangat merugikan bila terjadi di otak, berupa: 1) peningkatan kadar reactive oxygen species (ROS) yang menyebabkan stres oksidatif, 2) perubahan fungsi dari 
Tabel 1. Penelitian mengenai kerusakan yang terjadi akibat penggunaan dosis rendah radiasi

\begin{tabular}{|c|c|c|c|c|c|}
\hline No & Penelitian, tahun & Jenis penelitian & Perlakuan & Hasil & Kesimpulan \\
\hline 1 & $\begin{array}{l}\text { Rothkamm dan } \\
\text { Lo"brich, 2003. }{ }^{16}\end{array}$ & $\begin{array}{l}\text { Penelitian terhadap } \\
\text { sel primer fibroblast } \\
\text { (garis sel MRC-5), } \\
\text { diperiksa DSBs yang } \\
\text { terjadi pasca radiasi x } \\
\text {-ray dosis rendah. }{ }^{16}\end{array}$ & $\begin{array}{l}\text { Pemberian } \mathrm{x} \\
\text {-Ray dengan } \\
\text { dosis } \\
\text { berkisar } 1.2 \\
\text { mGy - } 2 \\
\text { Gy. }^{16}\end{array}$ & $\begin{array}{l}\text { Ditemukan adanya } \\
\text { hubungan linier antara } \\
\text { jumlah objek yang } \\
\text { diinduksi per sel } \\
\text { setelah } 3 \text { menit, } \\
\text { menunjukkan bahwa } \\
\text { setelah paparan sinar- } \\
\text { X sel rusak tidak } \\
\text { mengalami perbaikan, } \\
\text { sehingga kerusakan } \\
\text { terjadi dinilai sebagai } \\
\text { perubahan yang } \\
\text { persisten dan terjadi } \\
\text { beberapa perubahan } \\
\text { molekuler dalam sel } \\
\text { MRC-5. }{ }^{16}\end{array}$ & $\begin{array}{l}\text { Asumsi transfer energi linier } \\
\text { radiasi lebih tinggi } \\
\text { (LET) menyebabkan kerusakan } \\
\text { DNA yang lebih kompleks } \\
\text { secara umum diterima. }{ }^{16}\end{array}$ \\
\hline 2 & Antonelli et al,2015. ${ }^{17}$ & $\begin{array}{l}\text { Penelitian dilakukan } \\
\text { pada sel fibroblat (sel } \\
\mathrm{g}-\mathrm{H} 2 \mathrm{AX}) .{ }^{17}\end{array}$ & $\begin{array}{l}\text { Dilakukan } \\
\text { penyinaran } \\
\text { X-ray } \\
\text { dengan } \\
\text { dosis } 0,25- \\
0,5 \text { gray. }{ }^{17}\end{array}$ & $\begin{array}{l}\text { Pasca radiasi terdapat } \\
\text { penurunan jumlah sel } \\
\text { dimana terdapat } \\
\text { hubungan linier antar } \\
\text { keduanya. }{ }^{17}\end{array}$ & $\begin{array}{l}\text { Semakin besar dosis radiasi } \\
\text { maka semakin besar nilai } \\
\text { partikel radiasi yang ada di } \\
\text { dalam sel, yang membuat } \\
\text { perubahan sel meningkat, } \\
\text { sehingga jumlah sel normal } \\
\text { semakin menurun. }{ }^{17,18}\end{array}$ \\
\hline 3 & Okada et al,2007. ${ }^{19}$ & $\begin{array}{l}\text { Penelitian dilakukan } \\
\text { pada sel fibroblast III } \\
\text { (HFL III) paru-paru } \\
\text { manusia normal }{ }^{17-22}\end{array}$ & $\begin{array}{l}\text { Penelitian } \\
\text { dilakukan } \\
\text { dengan } \\
\text { melihat efek } \\
\text { biologis dari } \\
\text { dosis rendah } \\
\text { radiasi (X- } \\
\text { ray).34 }\end{array}$ & $\begin{array}{l}\text { Ditemukan bahwa } \\
\text { pertumbuhan } \\
\text { sel yang diradiasi } \\
\text { melambat dari } \\
\text { kelompok kontrol dan } \\
\text { mencapai penuaan } \\
\text { lebih dulu. Proses } \\
\text { penuaan terjadi } \\
\text { karena adanya } \\
\text { pembentukan DNA } \\
\text { DSB. }{ }^{17-22}\end{array}$ & $\begin{array}{l}\text { Perubahan sel terjadi karena } \\
\text { dosis rendah radiasi dan tidak } \\
\text { menunjukkan korelasi terhadap } \\
\text { akumulasi dosis radiasi. }{ }^{17-22}\end{array}$ \\
\hline 4 & $\begin{array}{l}\text { Roch-Lef'evre et } \\
\text { al,2016. }{ }^{23}\end{array}$ & $\begin{array}{l}\text { Membandingkan } \\
\text { induksi kromosom } \\
\text { kerusakan pada } \\
\text { limfosit tikus setelah } \\
\text { pemberian dosis } \\
\text { rendah radiasi. } \\
23\end{array}$ & $\begin{array}{l}\text { Pemberian } \\
\text { dosis X-ray } \\
\text { sebesar } 0,1 \text {, } \\
0,2 \text {, atau } 0,5 \\
\text { Gy. }^{23}\end{array}$ & $\begin{array}{l}\text { Ditemukan bahwa } \\
\text { setelah dilakukan } \\
\text { penyinaran } 0,1 \mathrm{~Gy} \\
\text { terdapat kematian } \\
\text { pada kromoson lebih } \\
\text { tinggi dari nilai rata- } \\
\text { rata. }^{23}\end{array}$ & $\begin{array}{l}\text { Kerusakan pada kromoson tikus } \\
\text { berjalan linier dengan besar nya } \\
\text { radiasi yang diberikan bahkan } \\
\text { dalam dosis kecil sekalipun. }{ }^{23}\end{array}$ \\
\hline 5 & $\begin{array}{l}\text { Katelyn Truong et al, } \\
\text { 2017. }^{24}\end{array}$ & $\begin{array}{l}\text { Penelitian dilakukan } \\
\text { pada sel fibroblast } \\
\text { secara in vitro. }\end{array}$ & $\begin{array}{l}\text { Pemberian } \\
\text { sinar-X dosis } \\
\text { rendah }(550 \\
\mu G y) .{ }^{24}\end{array}$ & $\begin{array}{l}\text { Ditemukan sel } \\
\text { berkembang biak } \\
\text { lebih, apoptosis yang } \\
\text { mungkin terjadi } \\
\text { karena menyebabkan } \\
\text { kerusakan DNA untai } \\
\text { ganda, akan tetapi } \\
\text { akan cepat di perbaiki } \\
\text { oleh tubuh. }{ }^{24,25}\end{array}$ & $\begin{array}{l}\text { Radiasi sinar-X dosis rendah } \\
\text { berdampak pada mitosis sel } \\
\text { sehingga } \\
\text { menyebabkan ekspresi } \\
\text { penuaan lebih awal, kerusakan } \\
\text { DNA cepat dikoreksi akan tetapi } \\
\text { setelahnya sel berkembang } \\
\text { lebih cepat setelah. }{ }^{26}\end{array}$ \\
\hline 6 & $\begin{array}{l}\text { Montree Tungjai et al, } \\
\text { 2017. }^{27}\end{array}$ & $\begin{array}{l}\text { Penleitian dilakukan } \\
\text { pada membran } \\
\text { mitokondria dalam } \\
\text { fungsi apoptosis, dan } \\
\text { regulasi siklus sel. }^{27}\end{array}$ & $\begin{array}{l}\text { Dilakukan } \\
\text { radiasi } \\
\text { dengan } \\
\text { dosis x-ray } \\
0,1-0,3 \\
\text { Hgray. }\end{array}$ & $\begin{array}{l}\text { Hasil menunjukkan : } \\
\text { tidak terdapat } \\
\text { perubahan yang } \\
\text { signifikan dari pasca } \\
\text { penyinaran, baik pada } \\
\text { membaran } \\
\text { mitokondria, apoptosis } \\
\text { dan siklus sel. }^{27}\end{array}$ & $\begin{array}{l}\text { Sinar } x \text { ray dengan dosis rendah } \\
\text { tidak memberikan efek kepada } \\
\text { perubahan pada mitokhondia } \\
\text { manusia secara in vitro. }{ }^{27}\end{array}$ \\
\hline 7 & $\begin{array}{l}\text { Zhuo Wang et al, } \\
2020 .^{28-29}\end{array}$ & $\begin{array}{l}\text { Penelitian dilakukan } \\
\text { pada sell Chinese } \\
\text { hamster } \\
\text { ovary Dalam studi ini, } \\
\text { kami akan } \\
\text { menyelidiki efek } \\
\text { sangat rendah dan } \\
\text { sinar-X dosis rendah } \\
\text { pada morfologi sel, } \\
\text { viabilitas, membran } \\
\text { permeabilitas, } \\
\text { apoptosis, dan } \\
\text { mutasi DNA. }{ }^{28-29}\end{array}$ & $\begin{array}{l}\text { Dilakukan } \\
\text { pemeriksaan } \\
\text { x-ray pada } \\
\text { dosis } \\
\text { radiasi : } 0.01 \\
-0,04 \text { Gy }(1-4 \\
\mu G y){ }^{28-29}\end{array}$ & $\begin{array}{l}\text { Hasil menunjukkan: }{ }^{28-} \\
\text { 1. Pada morfologi dan } \\
\text { pertumbuhan sel } \\
\text { tidak terdapat } \\
\text { perbedaan antara } \\
\text { kelompok radiasi } \\
\text { dan kontrol } \\
\text { 2. Viabilitas seluler } \\
\text { terjadi peningkatan } \\
\text { sampai } 11,7 \% \text { lebih } \\
\text { tinggi } \\
\text { 3. Aktifitas membran } \\
\text { menurun krn } \\
\text { terganggunya } \\
\text { fungsi. }\end{array}$ & $\begin{array}{l}\text { Tidak terlihat perubahan sel } \\
\text { secara signifikan. }{ }^{28-29}\end{array}$ \\
\hline
\end{tabular}


mitokondria, 3) menghilangnya plastisitas sinaptik, 4) perubahan struktur saraf dan 5) gangguan mikrovaskulatur, baik secara individu maupun kombinasi yang berkontribusi pada penyakit neurodegeneratif. ${ }^{35}$

\section{KELEBIHAN PENGGUNAAN DOSIS RENDAH RADIASI}

Pemanfaatan dosis rendah radiasi, pada beberapa dekade terakhir memberikan banyak praduga. Beberapa penelitian menunjukkan bahwa organisme dan sel dapat beradaptasi dengan paparan dosis rendah. ${ }^{36}$ Manusia dalam kehidupan sehari-hari, terus menerus terkena radiasi alami dengan dosis rendah (rata-rata 2,4 mSv) dari radon, sinar kosmik, sumber terestrial dan emisi internal isotop radioaktif dalam makanan dan air. Manusia juga terpapar sumber antropogenik radiasi yang digunakan dalam pengobatan, penelitian, dan industri yang berkontribusi sekitar 20\% dari total paparan radiasi. Radiasi dengan tujuan medis juga turut berkontribusi walaupun sebagian kecil. ${ }^{36}$ Banyak penelitian menunjukkan bahwa LDR tidak memiliki target dalam efek yang ditimbulkannya, termasuk efek respons adaptif, ketidakstabilan genom, respons terkoordinasi dan efek lainnya. Dua hipotesis yang bersaing mengajukan penjelasan tentang efek paparan LDR yang mengasumsikan bahwa tidak hubungan ada antara ambang batas dosis terhadap resiko peningkatan resiko. Penelitian baru bahkan membuktikan bahwa LDR bahkan mungkin bermanfaat bagi kesehatan meskipun dosis yang lebih besar berbahaya. ${ }^{37}$

Liu et all, dalam penelitiannya, menemukan bahwa respon adaptif sitogenetik yang diinduksi oleh dosis rendah radiasi mampu meningkatkan toleransi kromosom dan DNA terhadap kerusakan hal ini di sebabkan mekanisme molekuler mentransduksi sinyal sel dan pelindung ekspresi protein. Selanjutnya LDR kemungkinan menstimulasi fungsi kekebalan tubuh dengan mentransduksi sinyal sel T, meningkat ekspresi gen pemicu kekebalan, sitotoksik efek anti tumor, meningkatkan kemampuan pembentukan antibodi, dan mengaktivasi reaksi T-sel-ke-sel. LDR juga diduga meningkatkan kemampuan antikarsinogenesis dan menghambat tumor untuk tumbuh dan bermetastases. ${ }^{38-43}$

\section{DISKUSI}

Pemanfaatan radiasi dosis rendah (LDR) dalam diagnostik pencitraan contohnya pencitraan ekstremitas, radiografi dada, radiografi gigi, hanya menggunakan beberapa mikrosievert. Namun, pada kondisi tertentu dimana dibutuhkan $\mathrm{CT}$, dosis radiasi dapat melonjak menjadi sekitar $100 \mathrm{mSv}$ atau lebih. ${ }^{44}$ Dalam melakukan pajanan radiasi, risiko kesehatan yang terjadi sampai saat ini dikatakan bahwa pada dosis rendah sepenuhnya tidak memberikan bukti efek samping yang jelas, asalkan dosis pemberian ada pada rentang $100 \mathrm{mSv}$ (mGy). ${ }^{45}$

Hubungan dosis terhadap respons yang terjadi pada penggunaan LDR saat ini sulit dipastikan, karena hubungannya tidak jelas dan sulit dibuktikan. Banyak studi eksperimental mulai dari bakteri hingga manusia mencoba membuktikan antara LDR dan efek samping yang ditimbulkannya atau kelainan lainnya. ${ }^{46,47}$ Efek yang terjadi diperiksa baik yang dianggap menguntungkan ataupun yang merugikan. ${ }^{48}$ UNSCEAR mendiefinisikan LDR sebagai dosis yang $<100$ mGy $(01-1 \mathrm{~Gy}) .^{48}$ Sejumlah penelitian telah menunjukkan reaksi biologis yang spesifik, dimana terlihat adanya mekanisme respon adaptif yang cukup merugikan, dengan demikian beberapa laporan dan publikasi mendefinisikan radioadaptif respon sebagai kondisi kemampuan radiasi dosis rendah untuk menginduksi perubahan seluler yang mengubah atau merusak secara induksi ataupun spontan. ${ }^{49-51}$

Radiasi dosis rendah menyebabkan mekanisme biologis yang membuat sel lebih mampu mengatasinya dosis eksposur berikutnya ke dosis tinggi. Adaptif pertama akan merespon radiasi dosis rendah (1-100 mGy) dan megendalikan kerusakan sehingga lebih tahan terhadap radiasi berikutnya yang lebih tinggi, hal ini dinilai menguntungkna bagi tubuh. Oliveri dkk, melaporkan terjadi lebih sedikit penyimpangan kromatid pada sel yang sebelumnya terpapar pada dosis rendah radiasi. ${ }^{49}$ Berbagai deskripsi penelitian membuktikan bahwa penggunaan dosis rendah radiasi mampu merangsang pertahanan alami tubuh secara luas. Hal ini melalui berbagai penelitian dari beberapa organisme yang menunjukkan bahwa fenomena in bersifat evolusioner yang bersifat menurun..$^{50}$ Akan tetapi proses adaptasi yang dilakukan pada kultur jaringan juga mengakibatkan perubahan pada jaringan yang kemudian beradaptasi menjadi lebih kuat, dan ada kalanya kondisi ini justru tidak menguntungkan bagi tubuh, terlebih apabila orgamisme tersebut terdiri dari multisel. ${ }^{52}$

Pada tingkat molekuler jalur pensinyalan kunci yang telah diidentifikasi, apabila terinduksi oleh radiasi akan direspon langsung oleh DNA disertai reactive oxygen species (ROS), kemudian sel akan beradaptasi dengan kondisi DNA dan ROS baru demi kelangsungan hidup sel. Proses adaptif yang tercatat terjadi pada tingkat sel berupa penghapusan organel yang rusak melalui autophagy atau menghilangkan sel yang rusak melalui apoptosis atau nekrosis, atau dengan penundaan siklus sel atau protein bereplikasi.

Akhirnya, proses jaringan atau organisme yang terlibat dalam respon ini dengan menginduksi proliferasi atau diferensiasi sel, dengan mengendalikan reaksi imun, inflamasi, mendorong ekskresi zat beracun melalui transporter, atau mengaktifkan sel-sel melalui efek abscopal. ${ }^{53-55}$

Pada tingkat DNA respon dar kerusakan akan segera diperbaiki melalui mekanisme deteksi dan perbaikan lesi DNA. ${ }^{56}$ Kerusakan endogen atau eksogen menyebabkan beberapa sistem perbaikan DNA dari jalur berbeda, termasuk perbaikan eksisi dasar nukleotida, perbaikan eksisi homolog dan non -homolog. ${ }^{57,58}$ Sel mamalia dapat mengalami kerusakan DNA dari endogen yang melibatkan faktor seperti metabolisme oksidatif dan dari 
eksogen dapat berupa paparan radiasi. ${ }^{58}$ Studi terjadinya pengaturan dan penekanan pada proses eksperimental telah melaporkan induksi LDR pada DNA menyebabkan mekanisme perbaikan termasuk DNA-dependent protein kinase (DNA-PK) dan ERCC5 (XPG). Hasil dari eksperimen ini menekankan adanya peranan p53 dalam menginduksi respons adaptif, dikatakan respon adapatif perbaikan DNA pasca pemebrian LDR dipengarui oleh kadar p53. ${ }^{57}$ Borham dan Mitchel dalam penelitiannya menunjukkan bahwa singgle DNA jauh lebih radioresisten dibandingkan yang untai ganda, untuk itu diperlukan reaksi adaptif lebih cepat. $^{59}$

Pada tingkat sel, mekanisme adaptif terjadi untuk mempertahankan lingkungan intraseluler yang stabil sehingga sel dapat menanggapi stres fisiologis atau rangsangan patologis. Reaksi diperoleh dari berbagai cara, mulai dari pengaktifan jalur pertahanan untuk inisiasi kematian sel atau melalui mekanisme pertahanan evolusioner berupa jalur respons stres. Li et al. menjelaskan bahwa pada tingkat sel, proses pertahanan berupa respon sitoprotektif termasuk autofagi, yang memungkinkan kelangsungan hidup sel dengan cara degradasi dan daur ulang komponen sel, regulasi siklus sel, proliferasi, atau diferensiasi sel, yang memungkinkan pembentukan kembali retikulum endoplasma normal, memperbaiki fungsi, dan apoptosis yang terarah. ${ }^{60}$ Apoptosis adalah proses fisiologis terprogram dengan cara mematikan sel yang dimediasi oleh berbagai faktor endogen dan rangsangan eksogen termasuk radiasi. Beberapa penelitian membuktikan bahwa respon apoptosis lebih baik pada dosis rendah radiasi sehingga dikatakan lebih radioresponsive di bandingkan dosis tinggi. ${ }^{61}$ Perbaikan DNA akan menyebabkan

apoptosis sel. ${ }^{62}$

Pada sistem kekebalan tubuh, radiasi dosis rendah sangat berpengaruh untuk menjaga lingkungan sel agar tetap aman dan bertahan dari berbagai kerusakan. ${ }^{18}$ Pada salah satu penelitian dikatakan bahwa pengaruh LDR terhadap hormon terjadi reaksi memperbaiki sel yang secara signifikan lebih tinggi dari pada radiasi dosis tinggi. Hal ini menjelaskan bahwa terbentuk kekebalan tubuh baru karenanya. Peningkatan dosis LDR memiliki respon imun terutama untuk kekebalan adaptif. $^{63}$ Liu dkk dalam penelitiannya menjelaskan bahwa penyinaran $0,2 \mathrm{Gr}$ terjadi penurunan apoptosis sel. ${ }^{64,65}$ LDR juga mengubah sekresi sitokin dan diferensiasi T-helper. Protein tingkat interleukin 10 (IL-10) ditekan sementara ekspresi IL12 dirangsang, sehingga memungkinkan terjadinya pergeseran respon imun yang mendukung diferensiasi Th1. Selain itu, efek biologis LDR pada sel Natural Killer ternyata menyebabkan sel NK bertahan hidup lebih lama dan tahan terhadap apoptosis, hal ini menyebabkan reaksi inflamasi berlkangsung lebih lama dari biasanya. ${ }^{64,65}$ Yang et al juga menemukan adanya ekspansi dan sitotoksisitas sel NK secara signifikan dikarenakan LDR. Interferon-g dan kadar TNF- $\alpha$ juga meningkat sejalan peningkatan hidup sel NK. Temuan ini juga menunjukkan LDR menginduksi ekspansi dan aktivasi sel NK mungkin melalui jalur p38-MAPK7. Hasil akhir dari penelitian yang menunjukkan bahwa LDR meningkatkan respon kekebalan dengan cara menambah respon proliferasi-reaktif dan menekan respon apoptosis-reaktif dari sel imun, mengubah populasi sel kekebalan, dan pelepasan sitokin, melalui jalur transduksi sinyal yang

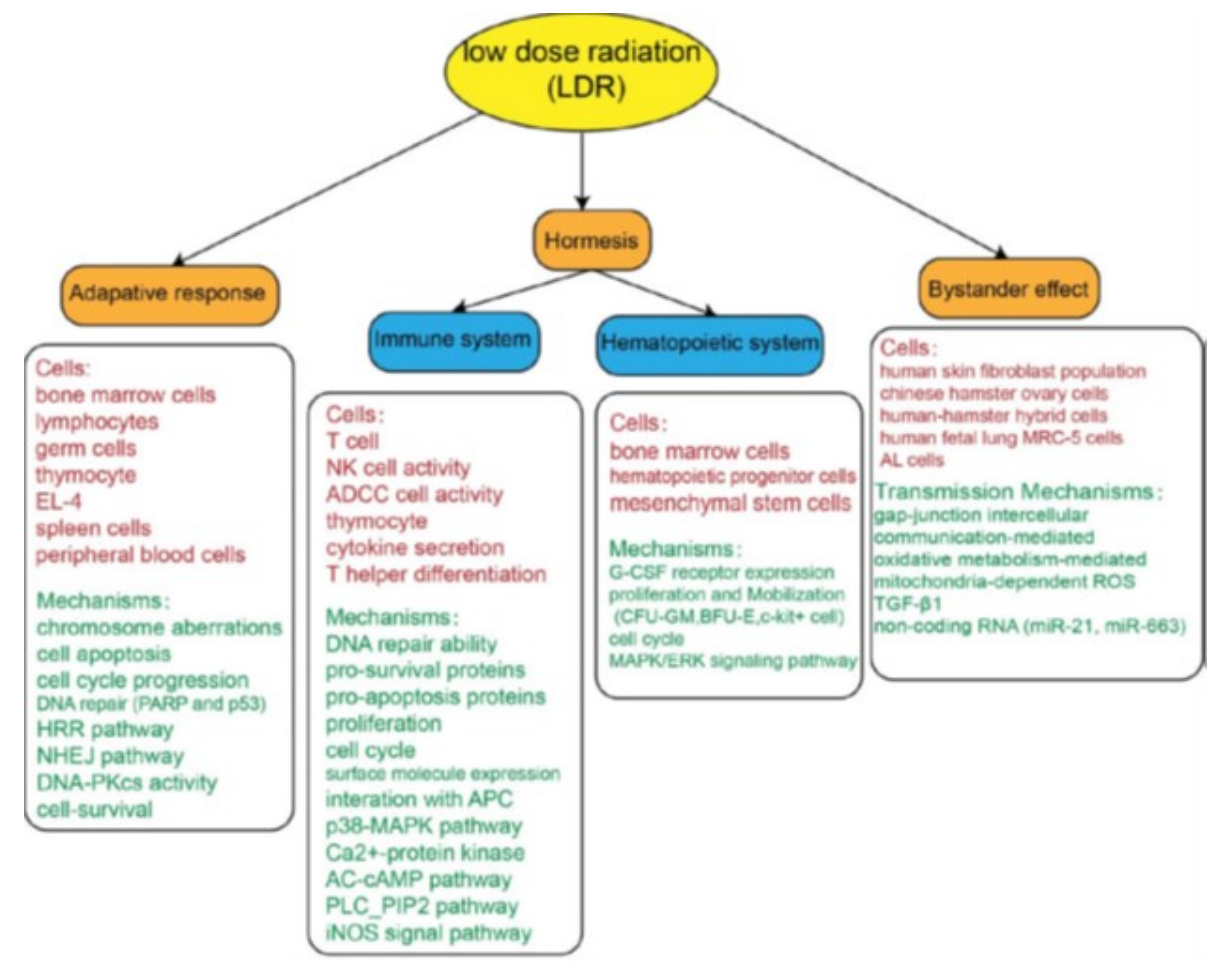

Gambar 1. Memperlihatkan pathway respon tubuh terhadap LDR dilihat dari repos adaptif, sistem imun, sistem hemapoitik dan sel. ${ }^{66}$ 
kompleks (gambar 1). ${ }^{66}$

Respon LDR pada sistem hematopoietik merupakan penelitian baru, dimana dijelaskan bahwa LDR dapat menginduksi hormon hematopoietik, sehingga sering fungsi hematopoietik mengalami depresi dikarenakan sistem ini merupakan sistem yang radiosensitive. ${ }^{67,68}$ Zhang st al, meneliti tentang efek LDR pada sistem hemopoitik melalui koloni granulosit pada ekspresi reseptor faktor pada permukaan sel sumsum tulang (BMC). Pada penelitian ini ditemukan adanya efek stimulasi oleh LDR pada hematopoietik berupa proliferasi sel. ${ }^{69,70}$ $\mathrm{Li}$ et all, melaporkan sumsum tulang mengalami proliferasi (unit pembentuk koloni granulositmakrofag dan pembentukan eritroid) secara signifikan terutama pada penyinaran $75 \mathrm{mGy} .{ }^{68-71}$ Sistem hematopoietik terutama bone marrow, akan lebih banyak memprodukdi sel leukosit, akan tetapi setelah terkena LDR sifatnya berploriferasi menjadi lebih banyak memproduksi makrofag dan eritrosit, selain itu sel punca mesenchymal (MSCs) produksinya juga terlihat meningkat. Pernyataan yang sama diutarakan oleh Liang et al, yang menujukkan terjadinya proliferasi MSC secara signifikan meningkat setelahnya pajanan LDR. ${ }^{72,73,74}$

Berdasar pada berbagai penelitian tentang efek biologis yang diinduksi oleh penggunaan LDR, maka terlihat bahwa radiasi dosis rendah mempengaruhi tubuh dengan merusak struktur DNA, melekul, sel dan juga faktor lainnya. Perubahan ini akan menimbulkan respon adaptif dari sel yang terkena yang terkadang menguntungkan bagi tubuh, walaupun ada juga yang cukup merugikan bagi tubuh.

\section{SIMPULAN}

Radiasi dosis terendah tetap menyebabkan perubahan yang cukup berarti pada tubuh karena mampu menyebabkan perubahan pada DNA, sel, molekuler dan biomarker walaupun kondisi ini ditanggapi dengan reaksi adaptif yang terkadang dianggap sebagai respon yang menguntungkan. Oleh karena itu, sekecil apapun radiasi pengion yang diberikan maka akan tetap membawa dampak bagi tubuh sehingga sebaiknya tetap bijaksana dalam pemanfaatann

\section{DAFTAR PUSTAKA}

1. Zhuo Wang, Ming Yue Lv, YaoXiong Huang. Effects of LowDose X-Ray on Cell Growth, Membrane Permeability, DNA Damage and Gene Transfer Efficiency, Dose-Response: An International Journal. Oktober-Desember. 2020:1-11

2. Ionizing radiation, health effects and protective measures. WHO. 2016. Accessed April 2016. https://www.who.int/news $\mathrm{room} / \mathrm{fa} \quad \mathrm{ct}$-sheets/detail/ionizing-radiation-health-effectsand-protectivemeasures, 2020

3. Shah DJ, Sachs RK, Wilson DJ. Radiation-induced cancer: a modern view. Br J Radiol. 2012;85(1020):1166-1173.

4. Farooque A, Mathur R, Verma A, et al. Low-dose radiation therapy of cancer: role of immune enhancement. Expert Rev Anticancer Ther. 2011;11(5):791-802.

5. Dhawan G, Kapoor R, Dhawan R, et al. Low dose radiation therapy as a potential life saving treatment for COVID-19 induced acute respiratory distress syndrome (ARDS) Radiother Oncol. 2020;147:212-216.

6. Cuttler JM. Application of low doses of ionizing radiation in medical therapies. Dose-Response. 2020;18(1):1-17.

7. Royo LT, Redondo GA, Pianetta MA, Prat MA. Low-dose radiation therapy for benign pathologies. Rep Pract Oncol Radiother. 2020;25(2):250-254.

8. Feinendegen LE. Evidence for beneficial low level radiation effects and radiation hormesis. Br J Radiol. 2005;78(925):3-7.

9. Noriko Shimura, Shuji Kojima. The Lowest Radiation Dose Having Molecular Changes in the Living Body. An International Journal . April-June. 2018:1-17

10. Biological Mechanisms of Radiation Actions at Low Doses: A White Paper to Guide the Scientific Committee's future programme of work. United Nations Scientific Committee on the Effect of Atomic Radiation; 2012.

11. Nakano T, Xu X, Salem AM, Shoulkamy MI, Ide H. Radiationinduced DNA-protein cross-links. Mechanisms and biological significance. Free Radic Biol Med. 2017:136-145

12. BF Wall, GM Kendall, A A Edwards, S Bouffler, CR Muirhead, JR Meara, What are the risks from medical X-rays and other low dose radiation?. The British Journal of Radiology, 79 (2006), 285-294

13. Noriko Shimura, Shuji Kojima, The Lowest Radiation Dose Having Molecular Changes in the Living Body, An International Journal April-June 2018:1-17

14. Nakano T, Xu X, Salem AM, Shoulkamy MI, Ide H.Radiationinduced DNA-protein cross-links. Mechanisms and biological significance. Free Radic Biol Med. 2017:136-145.

15. Goodhead DT. Initial events in the cellular effects of ionizing radiations: clustered damage in DNA, Int J Radiat Biol. 1994; 65(1):7-17.

16. Rothkamm K, Lo"brich M. Evidence for a lack of DNA doublestrand break repair in human cells exposed to very low X-ray doses. PNAS. 2003;100(9):5057-5062.

17. Antonelli F, Campa A, Esposito G, et al. Induction and repair of DNA DSB as revealed by $\mathrm{H} 2 \mathrm{AX}$ phosphorylation foci in human fibroblasts exposed to low- and high- LET radiation: relationship with early and delayed reproductive cell death Radiat Res. 2015; 183(4):417-431.

18. Feinendegen LE, Pollycove M. Biologic responses to low doses of ionizing radiation. Detriment versus hormesis. Part 1. Dose responses of cells and tissues. J Nucl Med. 2001;42(7):17N $27 \mathrm{~N}$.

19. Okada M, Okabe A, Uchihori Y, et al. Single extreme low dose/ low dose rate irradiation causes alteration in lifespan and genome instability in primary human cells. $\mathrm{Br} \mathrm{J}$ Cancer. 2007;96(11): 1707-1710.

20. Ishizaki $K$, Hayashi $Y$, Nakamura $H$, Yasui $Y$, Komatsu $K$ Tachibana A. No induction of $p 53$ phosphorylation and few focus formation of phosphrylated H2AX suggest efficient repair of DNA damage during chronic low-dose-rate irradiation in human cells. J Radiat Res. 2004;45(4):521-525.

21. Brooks AL, Lei XC, Rithidech K. Changes in biomarkers from space radiation may reflect dose not risk. Adv Space Res. 2003; 31(6):1505-1512.

22. Brooks AL, Hoel DG, Preston RJ. The role of dose rate in radiation cancer risk: evaluating the effect of dose rate at the molecular, cellular and tissue levels using key events in critical pathways following exposure to low LET radiation. Int J Radiat Biol. 2016; 92(8):405-426.

23. Roch-Ref'evre S, Martin-Bodiot C, Gr'egoire E, Desbr'ee A Roy L, Barquinero JF, A mouse model of cytogenetic analysis to evaluate caesium 137 radiation dose exposure and contamination level in lymphocytes. Radiat Environ Biophys. 2016;55(1):61-70.

24. Katelyn Truong, Suzanne Bradley, Bryana Baginski, Joseph R. Wilson, Donald Medlin, Leon Zheng, et al. The effect of wellcharacterized, very low-dose $\mathrm{x}$-ray radiation on fibroblasts, PlosOne.January, $2018: 1-16$.

25. Feinendegen LE. Evidence for beneficial low level radiation effects and radiation hormesis. Br J Radiol.2005; 78(925):3-7

26. Feinendegen LE. Relative implications of protective responses versus damage induction at low dose and low-dose-rate exposures, using the microdose approach. Radiat Prot Dosimetry. 2003; 104 (4):337- 46

27. Shay JW, Roninson IB. Hallmarks of senescence in carcinogenesis and cancer therapy. Oncogene. 2004; 23 (16):2919-33

28. Montree Tungjai, Nutnicha Phathakanon, Kanokporn Noy Rithidech. Effects of medical diagnostic low-dose $x$ rays on human lymphocytes: mitochondrial membrane potential, apoptosis and cell cycle. Health Phys. 2017.112(5): 458-464 
29. Alexander Vaiserman1, Alexander Koliada1, Oksana Zabuga1,Yehoshua Socol2. Health Impacts of Low-Dose Ionizing Radiation: Current Scientific Debates and Regulatory Issues. An International Journal July-September 2018:1-27

30. Nowosielska EM, Cheda A, Wrembel-Wargocka J, Janiak K. Effect of low doses of low-LET radiation on the innate antitumor reactions in radioresistant and radiosensitive mice. Dose- Response. 2012;10(4):500-515.

31. Bogda'ndi EN, Balogh A, Felgyinszki $N$, et al. Effects of lowdose radiation on the immune system of mice after totalbody irradiation. Radiat Res. 2010;174(4):480-489.

32. Lacoste-Collin L, Jozan S, Cances-Lauwers V, et al. Effect of continuous irradiation with a very low dose of gamma rays on life span and the immune system in SJL mice prone to B-cell lymphoma. Radiat Res. 2007;168(6):725-732.

33. Cuttler JM, Feinendegen LE, Socol Y. Evidence that lifelon low dose rates of ionizing radiation increase lifespan in longand short-lived dogs. Dose-Response. 2017;15(1):1-6.

34. Seed TM, Inal C, Dobson ME, et al. Accomodative response to chronic irradiation: effects of dose, dose rate, and pharmacological response modifiers. Mil Med. 2002;167:82 86.

35. Caroline C. Rodgers. Low-dose X-ray imaging may increase the risk of neurodegenerative diseases. Medical Hypotheses 2020;142:1-6

36. Yann Guéguen, Alice Bontemps, Teni G. Ebrahimian. Adaptive responses to low doses of radiation or chemicals: their cellular and molecular mechanisms. Cellular and Molecula Life Sciences. Desember 2018:1-18

37. Lagarde F, Beausoleil C, Belcher SM, Belzunces LP, Emond, C, Guerbet M, Rousselle C (2015) Non-monotonic doseresponse relationships and endocrine disruptors: a qualitative . Environ Health. 2015; 14 (13)

38. Liu Shuzheng, Shunzi Jin, Hongyu Jiang, Lu Cai. New understanding of the low-dose radiation-induced hormesis. Radiation Medicine and Protection 1. 2020: 2-6

39. Liu SZ, Jin SZ, Liu XD, et al. Role of CD28/B7 costimulation and II-12/IL-10 interaction in the radiation-induced immune changes. BMC Immunol. 2001;2:1-8.

40. Gao H, Dong Z, Wei W, et al. Integrative analysis for the role of long non-coding RNAs in radiation-induced mouse thymocytes responses. Acta Biochim Biophys Sin. 2017;49 (1):51-61.

41. Gao H, Dong Z, Gong X, et al. Effects of various radiation doses on induced T-helper cell differentiation and related cytokine secretion. J Radiat Res. 2018;59(4):395-403.

42. Liu SZ. Radiation-induced changes in lymphocyte proliferation and its neuroendocrine regulation: dose-response relationship and pathophysiological implications. Intl J Nonlinearity Biol Toxicol Med. 2004;2(3):133-243.

43. Alexander Vaiserman1, Alexander Koliada1, Oksana Zabuga1, and Yehoshua Socol, Health Impacts of Low-Dose Ionizing Radiation: Current Scientific Debates and Regulatory Issues. An International Journal. July-September . 2018:1-27

44. B F Wall, G M Kendall, A A Edwards, S Bouffler, C R Muirhead, J R Meara. What are the risks from medical X-rays and othe low dose radiation?. The British Journal of Radiology, 79 (2006), 285-294

45. L E Feinendegen. Evidence For Beneficial Low Level Radiation Effects And Radiation Hormesis. The British Journal of Radiology, 78 (2005), 3-7

46. Feinendegen LE. Relative implications of protective responses versus damage induction at low-dose and low-dose rate exposures, using the microdose approach. Radiat Prot Dosim 2003;104:337-46

47. Calabrese EJ, Baldwin LA. Toxicology rethinks its centra belief. Nature 2003;421:691-2.

48. Feinendegen LE. Biological effects of low doses of ionizing radiation: damage versus protection. In: LE Feinendegen, WW Shreeve, W Eckelman, Y-W Bahk, HN Wagner Jr, eds.Molecular Nuclear Medicine; The Challenge of Genomics and Proteomics to Clinical Practice. Heidelberg, New York, Springer Verlag 2003:747-61.

49. Calabrese EJ, Baldwin LA. The frequency of U-shaped dose responses in the toxicological literature. Toxicol Sci. 2001; 62 (2):330-338

50. Szumiel I. Ionizing radiation-induced oxidative stress, epigenetic changes and genomic instability: the pivotal role of mitochondria. Int J Radiat Biol. 2012; 91(1):1-12.

51. Tapio S, Jacob V. Radioadaptive response revisited. Radiat Environ Biophys. 2007; 46(1):1-12.

52. Sthijns MM, Weseler AR, Bast A, Haenen GR. Time in redox adaptation processes: from evolution to hormesis. Int J Mol Sci. 2016; 17(10):1649.
3. Andreau K, Leroux M, Bouharrour A. Health and cellula impacts of air pollutants: from cytoprotection to cytotoxicity. Biochem Res Int.2012:493894.

54. Tapio S, Jacob V. Radioadaptive response revisited. Radiat Environ Biophys . 2007; 46(1):1-12.

55. Calabrese EJ. Hormetic mechanisms. Crit Rev Toxicol . 2013; 43(7):580-606.

56. Harper JW, Elledge SJ. The DNA damage response: ten years after. Mol Cell. 2007; 28(5):739-745

57. Sasaki MS, Ejima Y, Tachibana A, Yamada T, Ishizaki K, Shimizu T, Nomura T. DNA damage response pathway in radioadaptive response. Mutat Res. 2002; 504(1-2):101-118

58. Nenoi $M$, Wang $B$, Vares $G$. In vivo radioadaptive response: review of studies relevant to radiation-induced cancer risk. Hum Exp Toxicol. 2015; 34(3):272-283.

59. Iyer R, Lehnert BE. Alpha-particle-induced increases in the radioresistance of normal human bystander cells. Radiat Res. 2002; 157(1):3-7

60. Li N, Hao M, Phalen RF, Hinds WC, Nel AE (2003) Particulate air pollutants and asthma. A paradigm for the role of oxidative stress in PM-induced adverse health effects. Clin Immunol 109(3):250-265

61. Maes OC, An J, Sarojini $\mathrm{H}, \mathrm{Wu} \mathrm{H}$, Wang $\mathrm{E}$ (2008) Changes in MicroRNA expression patterns in human fibroblasts after lowLET radiation. J Cell Biochem 105(3):824-834

62. Gaipl US, Meister S, Lodermann B, Rodel F, Fietkau R, Herrmann M, Kern PM, Frey B. Activation-induced cell death and total Akt content of granulocytes show a biphasic cours after low-dose radiation. Autoimmunity.2009; 42(4):340-342

63. Kusunoki Y, Hayashi T. Long-lasting alterations of the immune system by ionizing radiation exposure: implications for disease development among atomic bomb survivors. Int J Radiat Biol. 2008;84(1):1.

64. Liu XD, Ma SM, Liu SZ. Effects of 0.075 Gy x-ray irradiation on the expression of IL-10 and IL-12 in mice. Phys Med Biol. 2003; 48(13):2041-2049.

65. Liu SZ, Jin SZ, Liu XD, Sun YM. Role of CD28/B7 costimulation and IL-12/IL-10 interaction in the radiation-induced immune changes. BMC Immunol. 2001;2(1):8.

66. Yang $\mathrm{G}$, Kong $\mathrm{Q}$, Wang $\mathrm{G}$, et al. Low-dose ionizing radiation induces direct activation of natural killer cells and provides a novel approach for adoptive cellular immunotherapy. Cancer Biother Radiopharm. 2014;29(10):428-434.

67. Mouthon MA, Meeren AVD, Vandamme $M$, Squiban $C$ Gaugler MH. Thrombopoietin protects mice from mortality and myelosuppression following high-dose irradiation: importance of time scheduling. Can J Physiol Pharmacol. 2002;80(7):717-721

68. Li W, Wang G, Cui J, Xue L, Cai L. Low-dose radiation (LDR) induces hematopoietic hormesis: LDR-induced mobilization of hematopoietic progenitor cells into peripheral blood circulation. Exp Hematol. 2004;32(11):1088-1096.

69. Zhang HL. Stimulation of low dose radiation on hematopoietic system. Zhonghua Yi Xue Za Zhi. 1993;73(2):99.

70. Zhang $L$. The hormesis of blood samples irradiated in vitro by Xrays to low doses. J Radiat Res Radiat Proc. 2004;22(5):315 317.

71. Wang GJ, Cai L. Induction of cell-proliferation hormesis and cellsurvival adaptive response in mouse hematopoietic cells by whole-body low-dose radiation. Toxicol Sci. 2000;53(2):369 -376 .

72. Senseb'e L, Bourin P. Mesenchymal stem cells for therapeutic purposes. Transplantation. 2009;87(9 suppl):49-53.

73. Liu ZJ, Zhuge $Y$, Velazquez OC. Trafficking and differentiation of mesenchymal stem cells. J Cell Biochem. 2009;106(6):984.

74. Liang XY, So YH, Cui JW, et al. The low-dose ionizing radiation stimulates cell proliferation via activation of the MAPK ERK pathway in rat cultured mesenchymal stem cells. J Radiat Res. 2011;52(3):380-386 